Richardson, A. N., N. Koper, and K. A. White. 2014. Interactions between ecological disturbances: burning and grazing and their effects on songbird communities in northern mixed-grass prairies. Avian Conservation and Ecology 9(2): 5. http://dx.doi.org/10.5751/ACE-00692-090205 Copyright (C) 2014 by the author(s). Published here under license by the Resilience Alliance.

Research Paper

\title{
Interactions between ecological disturbances: burning and grazing and their effects on songbird communities in northern mixed-grass prairies
}

\author{
Alexis N. Richardson ${ }^{1}$, Nicola Koper ${ }^{1}$ and Krystle A. White ${ }^{1}$ \\ ${ }^{1}$ University of Manitoba
}

\begin{abstract}
Historically, North American prairies were strongly influenced by two natural disturbances, fire and grazing, and their interaction. However, the frequency and size of fires has been greatly altered over time, while native ungulates have been replaced by livestock; this may have had strong ecological influences on modern prairies. The feedback hypothesis proposes that grazing by ungulates will increase the duration of fire effects because ungulates will be attracted to burned patches. We conducted point-count surveys in burned-grazed, burned-ungrazed, unburned-grazed, and unburned-ungrazed sites over a 5-year period following fires that occurred naturally in 2006 in southern Saskatchewan, Canada, to test predictions related to avian community composition related to the feedback hypothesis. Generalized linear mixed models were used to analyze interactions among burning, grazing, and time since burning. Six of the nine avian species we studied responded positively or negatively to burning or grazing, although there were few statistically significant effects on the vegetation structure variables we measured. We found mixed evidence that grazing increased the duration of effects of burning, cumulatively providing little evidence for the feedback hypothesis. Nonetheless, effects of burning and grazing differed from and interacted with one another; for example, short-term effects of burning on Sprague's Pipits (Anthus spragueii) and Baird's Sparrows (Ammodramus bairdii) were greater than effects of grazing, and effects of grazing and burning in combination were frequently greater than effects of a single disturbance. Therefore, both should be integrated into management for the conservation of grassland songbirds.
\end{abstract}

\section{Interactions entre des perturbations écologiques : les feux, le broutement et leurs effets sur les communautés de passereaux dans des prairies mixtes septentrionales}

RÉSUMÉ. Historiquement, les prairies d'Amérique du Nord étaient fortement influencées par deux perturbations naturelles, soit le feu et le broutement, et leurs interactions. Cependant, la fréquence et la taille des feux ont beaucoup changé depuis ce temps, et les ongulés indigènes ont été remplacés par le bétail; or, ces changements ont peut-être eu une grande influence écologique sur les prairies contemporaines. L'hypothèse de rétroaction sous-tend que le broutement par les ongulés augmentera la durée de l'effet des feux parce que les ongulés vont être attirés par les îlots brûlés. Nous avons effectué des dénombrements par points d'écoute dans des sites brûlésbroutés, brûlés-non broutés, non brûlés-broutés et non brûlés-non broutés, au cours des cinq années qui ont suivi les feux s'étant produits naturellement en 2006 dans le sud de la Saskatchewan, Canada, afin de tester les prédictions relatives à la composition des communautés aviaires selon l'hypothèse de rétroaction. Des modèles linéaires généralisés à effets mixtes ont été utilisés pour analyser les interactions entre les feux, le broutement et le temps écoulé depuis les feux. Six des neuf espèces d'oiseaux que nous avons examinées ont réagi positivement ou négativement aux feux ou au broutement, bien qu'il y ait eu peu d'effets statistiquement significatifs sur les variables touchant la structure de la végétation que nous avons mesurées. Nous avons obtenu des résultats contradictoires pour ce qui est de l'augmentation de la durée de l'effet des feux par le broutement; ces résultats supportent ainsi très peu l'hypothèse de rétroaction dans l'ensemble. Néanmoins, les effets des feux et du broutement étaient différents et interagissaient entre eux; par exemple, les effets à court terme des feux sur les Pipits de Sprague (Anthus spragueii) et les Bruants de Baird (Ammodramus bairdii) étaient supérieurs aux effets du broutement, et les effets combinés des feux et du broutement étaient souvent plus élevés que les effets d'une des deux perturbations prise seule. Par conséquent, les deux types de perturbation devraient être intégrés dans les mesures de gestion destinées à la conservation des passereaux de milieux de prairie.

Key Words: Baird's Sparrow; cattle grazing; Chestnut-collared Longspur; fire; mixed-grass prairie; Sprague’s Pipit

\section{INTRODUCTION}

Historically, the Great Plains experienced the most intense and frequent disturbances of any ecosystems within North America (Wright and Bailey 1982, Knopf and Samson 1997, Brawn et al. 2001). Fire, grazing, and the interaction between the two were common and influential disturbances (Higgins 1986, Knopf 1996,
Brawn et al. 2001). Thus, seasonal patterns of fire followed by grazing dominated the prairie landscape. However, North American grassland ecosystems changed significantly following European colonization. In the northern Great Plains, where bison (Bison bison) have been largely extirpated and wildfires are suppressed (Samson and Knopf 1994, Brawn et al. 2001, Lueders 
et al. 2006, Brudvig et al. 2007, With et al. 2008), this resulted in a significant reduction in critical natural disturbance processes from the prairies. This has had significant ecological consequences (Askins et al. 2007). Disturbances such as fire and grazing tend to cause the vegetation community to transition back to an earlier successional stage (Lesica and Cooper 1999, Madden et al. 1999, Brawn et al. 2001, Fritcher et al. 2004). In arid regions, removal of ecological disturbances results in increased growth of taller and denser grasses, increased litter and thus cooler and moister soil, increased or decreased productivity, and suppression of short-statured forbs or species that are not strong competitors (Madden et al. 1999, Brawn et al. 2001, Shay et al. 2001, ErichsenArychuk et al. 2002). Effects of fire and grazing also interact with climate. During wet years, productivity may increase following burns, whereas in dry years, productivity may decrease following burns (Shay et al. 2001, Erichsen-Arychuk et al. 2002).

The ecological effects of fire may be strongly influenced by the presence or absence of other types of disturbances. Forage quality can increase after fire because burning reduces the structural complexity of vegetation (Bailey 1988), increases the nutrient availability of the soil(Wright and Bailey 1982, Erichsen-Arychuk et al. 2002), and increases light penetration for emerging shoots by removing litter (Wright and Bailey 1982). For these reasons, burned areas are often preferentially grazed by ungulates, and over time maintain low fuel loads with higher amounts of bare ground. This reduces the probability of a second fire within the burned patch, whereas the unburned areas, which are less strongly selected by grazers, continually build up fuel loads from litter accumulation, which increases the probability of a fire within that area (Fuhlendorf et al. 2006). Further, because grazers are attracted to burned sites, grazed and burned patches are less likely to become fibrous and unpalatable to grazing animals in the years following a fire, and thus grazing can extend the duration of the burning effects (Bailey 1988, Fuhlendorf et al. 2006). When burning and grazing are both present in grassland ecosystems, these feedback mechanisms can create a mosaic of spatially and temporally distinct habitats that range from heavily disturbed patches to undisturbed patches (Fuhlendorf et al. 2006).

Grasslands of the modern northern Great Plains have become relatively homogeneous because of the replacement of most native ungulates with domestic livestock, and, in some regions, the suppression of fire (Higgins 1986, With et al. 2008). This landscape homogeneity may have significantly contributed to the steep recent declines of grassland bird populations (Brawn et al. 2001). Because grassland birds differ in their habitat preferences, common management recommendations that prescribe intermediate levels of grazing disturbance may not be the best approach for enhancing grassland bird diversity (Derner et al. 2009). This is especially true when managing landscapes to support multiple species. For example, two species that are considered federally threatened in Canada (Government of Canada 2012), Sprague's Pipit (Anthus spragueii) and Chestnutcollared Longspur (Calcarius ornatus), have opposing habitat requirements (Derner et al. 2009). Periodic and patchy defoliations by disturbances may be vital for maintaining biodiversity, and thus incorporating both fire and grazing into grassland management may be important for conserving species of the northern Great Plains.
Despite the importance of ecological disturbances to the conservation of grassland songbirds, studies of burning-grazing interactions in mixed-grass prairies are rare (Johnson 1997). Kruse and Bowen (1996) evaluated effects of burning and grazing on breeding waterfowl. Danley et al. (2004) measured songbird diversity in response to grazing only on burned prairies, while others evaluated effects of fire only in ungrazed prairies (e.g., Grant et al. 2010). Roberts et al. (2012) quantified effects of fire on songbirds in both grazed and ungrazed mixed-grass prairies, but did not evaluate effects of grazing on their results. Other studies regarding the interaction between fire and grazing have primarily been conducted in tall-grass prairie (e.g. Zimmerman 1997, Fuhlendorf et al. 2006, Powell 2006), because of the naturally high frequency and intensity of fires in temperate grasslands (Wright and Bailey 1982). However, because of differences in moisture regime, species composition, and habitat structure, effects of burning in tall-grass prairies are probably significantly different from effects in mixed-grass prairies (Wright and Bailey 1982, Askins et al. 2007). Our study is, to the best of our knowledge, the first to evaluate and analyze songbird responses to the full complement of burning-grazing interactions, i.e., burning only, grazing only, combined burning and grazing, and no disturbance, in mixed-grass prairies.

Our objectives were to evaluate (1) effects of the interactions between burning and grazing on the songbird community and vegetation structure, and (2) how these interactions changed with increasing time since fire. We hypothesized that effects of burning and grazing on birds were driven by effects of burning and grazing on vegetation structure, and thus predicted that as effects of burning on vegetation declined as years since burning increased, effects of burning on avian populations would similarly decline. We hypothesized that if there was a positive feedback mechanism between burning and grazing, effects of burning would last longer in grazed than ungrazed sites. This is hypothesized to occur if cattle are attracted to burned sites; subsequent heavy grazing of recently burned sites is predicted to maintain a short, open canopy, increasing light penetration and thus potential for palatable, nutritious regrowth, which would then attract more grazers, keeping the burned area relatively short for an extended period of time (e.g., Bailey 1988, Fuhlendorf et al. 2006). In contrast, sites that are burned but not grazed would be predicted to recover rapidly because burning produces good conditions for plant growth. In addition, we hypothesized that effects of burning and grazing might be additive, and thus, effects of both types of disturbance would be greater than effects of one disturbance alone. Because North American grassland communities evolved in the presence of grazing and fire, we predicted that species diversity would increase with grazing and fire (e.g., Madden et al. 1999, 2000). We predicted that species that respond positively to disturbance, including Chestnut-collared Longspur, McCown's Longspur (Rhynchophanes mccownii), and Horned Lark (Eremophila alpestris), would respond positively to burning and grazing; that species that respond negatively to disturbance, including Sprague's Pipits and Baird's Sparrows (Ammodramus bairdii), would respond negatively to burning and grazing; and that species that depend on shrubs for nest or perch sites, such as Clay-coloured Sparrows (Spizella pallida) and Western Meadowlarks (Sturnella neglecta), would decline if burning intensity was high enough to remove shrubs. We predicted fewer 
effects on habitat generalists such as Brown-headed Cowbird (Molothrus ater), Savannah Sparrow (Passerculus sandwichensis), and Vesper Sparrow (Pooecetes gramineus). We predicted that effects of burning would decline over time, while effects of grazing would remain consistent over time.

\section{METHODS}

\section{Study area}

Our mensurative experiment was conducted within the northern mixed-grass prairies of southern Saskatchewan, Canada, in the East Block of Grassland National Park (GNP) and adjacent community pastures, including the Mankota Community Pastures (MCP). Cattle grazing has been absent from GNP since 1985, after Parks Canada obtained the land rights from previous landowners (Parks Canada 2002). Although cattle have been reintroduced to some areas of the park, they were absent from our study area within the park. The Mankota and private pastures supported season-long cattle grazing at a low-moderate grazing intensity typical of the grazing intensity of this semiarid region (stocking rates for 2009 and 2010, the only years for which these data were available, $\mu=0.43 \mathrm{AUM} / \mathrm{ha}$ [Animal Unit Months / hectare], $\pm \mathrm{SD}=0.064$; see also Abouguendia 1990). Pastures were usually grazed from late May until mid-September.

Natural and prescribed burning has occurred rarely in the East Block of GNP and adjacent grazed pastures for numerous decades, because of fire suppression by the surrounding communities and Parks Canada staff (Parks Canada 2002). Despite this, in July of 2006, several wildfires occurred in this area, generating unburned-grazed (UB-G) and burned-grazed (BG) prairie in the Mankota and private grazing pastures, and burned-ungrazed (B-UG) and unburned-ungrazed (UB-UG) prairies in GNP (Figs. 1,2). Wildfires were limited to upland areas several hundred meters away from natural riparian zones in the region. Therefore, only upland prairies were surveyed throughout our study. Data collection took place in the five years following these burns, 2007 to 2011.

All sites consisted predominantly of native vegetation. Characteristic upland vegetation for this region includes needleand-thread grass (Hesperostipa comata), blue grama grass (Bouteloua gracilis), western wheatgrass (Pascopyrum smithii), and June grass (Koeleria macrantha). There are also some occurrences of lowland shrubs like silver sagebrush (Artemisia cana), western snowberry (Symphoricarpos occidentalis), and greasewood (Sarcobatus vermiculatus). The average precipitation in southern Saskatchewan for May, June, July, and August are 52, 65,54 , and $34 \mathrm{~mm}$, respectively (1971 through 2000, Val Marie; Government of Canada 2011). The summer of 2009 was drier than normal (22, 38, and $35 \mathrm{~mm}$ for May, June, and July) and in 2008, June (131 mm) and August (49 mm) were unusually wet. April, May (73 mm), and August (63 mm) in 2010, and May (88 $\mathrm{mm})$ and July (71 mm) in 2011, were also wetter than the historical average (Government of Canada 2011).

Native ungulates including mule deer (Odocoileus hemionus) and pronghorns (Antilocapra americana) occur throughout the study area, and could have affected our results if they were also attracted to burned areas. Their abundances are much lower, and their diets are somewhat different, from cattle, suggesting their effects
Fig. 1. Burned and unburned vegetation in East Block of Grasslands National Park of Canada, (a) 2006, (b) 2007, (c) 2008. Dashed white line approximately distinguishes perimeter of burns in 2007 and 2008. The 2006 photo illustrates heterogeneity of burn intensity. (Photos a and b by Robert Sissons; Photo c by Barbara Bleho.)

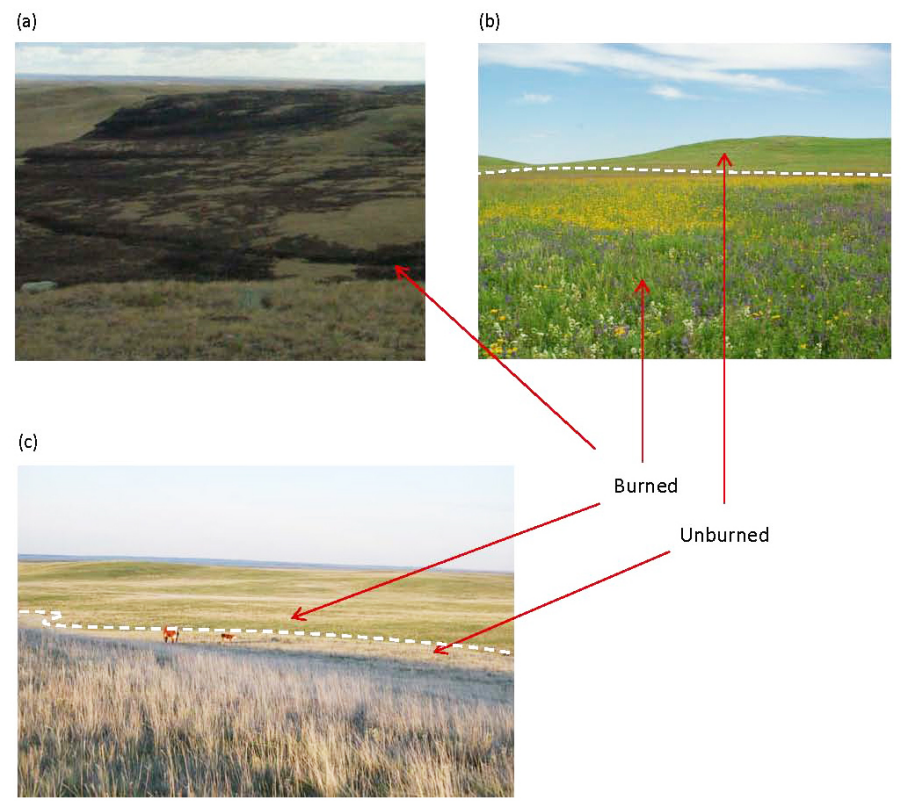

relative to cattle were probably small. Nonetheless, our study design only allows us to evaluate the additive effects of livestock on the grazing community, rather than presence and absence of grazing ungulates.

\section{Study design}

Five burns, ranging from 70 to 750 ha, were studied (Figs. 1, 2). Two burns were located in grazed prairie, one in ungrazed prairie, and two occurred half in grazed and half in ungrazed prairie. Burn intensities were similar among burns, generally moving quickly enough, because of windy conditions, to leave the moss and lichen layer relatively unscathed, while consuming the above-ground graminoid and forb canopy. Some silver sagebrush was killed by the fires, but many were not. Burn intensity within burns was heterogeneous and somewhat patchy, typical of naturally occurring grassland fires, and varied with substrate and wind activity (Fig. 1a). These five burns were divided into eight clusters of point-count plots, based on disturbance type and location: four burned-ungrazed (burns 1-4) and four burnedgrazed (burns 5-8) clusters, which were compared with four unburnedgrazed (pastures 10,11,13, and the unburned portion of pasture 12) and three unburned-ungrazed (pastures 1, 5 and 9; Fig. 2) clusters.

In 2008 and 2009, songbird surveys were conducted in 72, 3.2-ha plots: 17 plots in unburned-ungrazed, 21 plots in unburned-grazed, 18 plots in burned-grazed, and 16 plots in burned-ungrazed. Because of time and budget constraints in 2007, only 51 plots were sampled. Because of a change in grazing treatment in 2010, plots in pasture 10 (all unburned-grazed) could not be surveyed in 2010 and 2011. 
Fig. 2. Study design to evaluate effects of burning and grazing on grassland songbirds in southern Saskatchewan, Canada, 2007 to 2011. Point-count plots (white squares: burned; black circles: unburned) were distributed across the study area in clusters. Unburned-ungrazed clusters (pastures 1, 5, and 9) and burned-ungrazed clusters (burns 1-4) were in the East Block of Grasslands National Park. Most of the unburned-grazed clusters (pastures 10-13) and burned-grazed clusters (burns 5-7) were in the Mankota Community Pastures. One burned-grazed point-count cluster (burn 8) was in a private, grazed pasture. Pastures 2-4 and 6-8 were not used for our study as their grazing regimes varied over time.

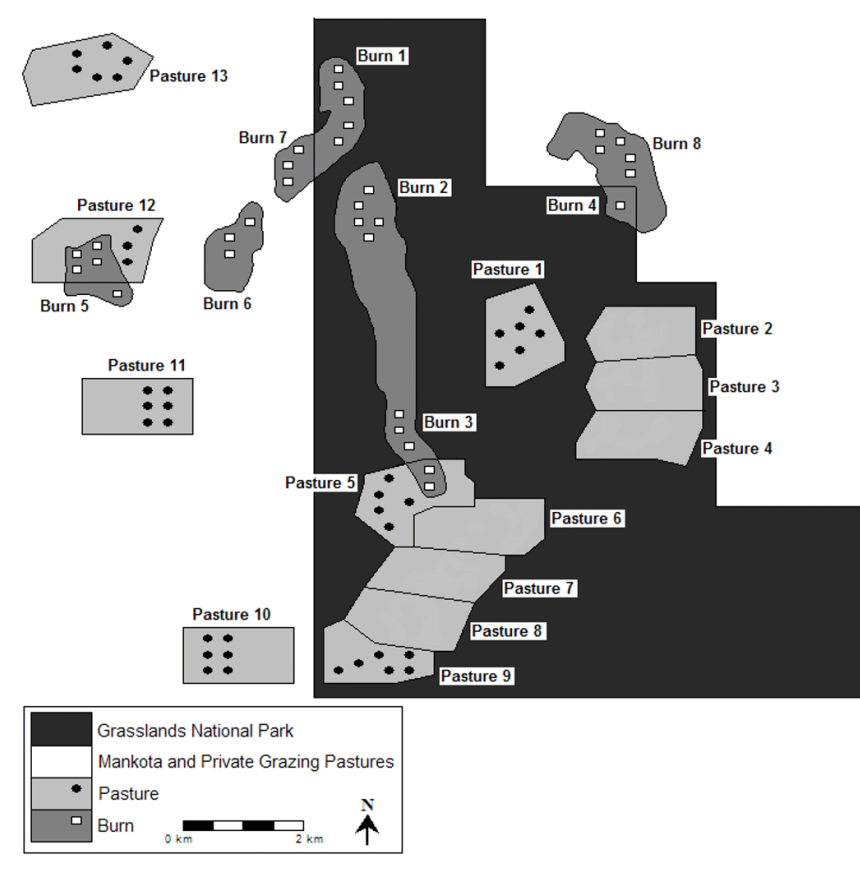

\section{Point-count surveys}

Songbird relative abundances were assessed using five-minute, 100-m radius point-count plots, within which all birds seen or heard were recorded. Point-count plot centers were placed at least $250 \mathrm{~m}$ apart to ensure that individuals were not counted in more than one plot. Surveys were not conducted when raining, foggy, or if wind exceeded $16 \mathrm{~km} / \mathrm{h}$ (Koper and Schmiegelow 2006, Lueders et al. 2006). Surveys were conducted between sunrise and 1000 hours in the first two weeks of June each year.

We chose to use unadjusted counts to indicate relative abundance of species for several reasons. Our empirical data based on 100$\mathrm{m}$ radius dependent double-observer point-counts in Canadian mixed-grass prairies ( $n=52$ plots, $n=8$ observers in 4 pairs, June 2012, analyzed using DOBSERV; Hines 2000) suggests very high perceptibility of Baird's sparrow, Vesper sparrow, Chestnutcollared Longspur, Sprague's Pipit, Savannah Sparrow, and Western Meadowlark $\left(P>0.96, \mathrm{LCL}_{95 \%}>0.90, \mathrm{UCL}_{95 \%}<1.06\right)$, and high perceptibility of Clay-coloured Sparrows, Horned Larks, and Brown-headed Cowbirds $\left(P>0.89, \mathrm{LCL}_{95 \%}>0.60\right.$, $\left.\mathrm{UCL}_{95 \%}<1.18\right)$. We dropped our analyses for Grasshopper
Sparrow (Ammodramus savannarum), for which we had only a small sample size, because our double-observer analyses suggested that perceptibility of Grasshopper Sparrow may be low, although the confidence interval for that species is very wide $(P$ $=0.56, \mathrm{LCL}_{95 \%}=-0.56, \mathrm{UCL}_{95 \%}=1.68 ; \mathrm{N}$. Koper, L. Leston, and P. Rosa, unpublished manuscript). A common alternative to using unadjusted counts, distance sampling, is more suited for forest ecosystems (Rotella et al. 1999) and its assumptions are difficult to meet in field situations (Johnson 2008, Efford and Dawson 2009). We did not meet the assumption of population closure for mixture models (Royle and Nichols 2003) or removal methods (Farnsworth et al. 2002) because of frequent movements of birds into and outside of plots during our surveys. Cumulatively, these conclusions are consistent with other research that has been conducted in mixed-grass prairies of southern Alberta, which demonstrated that unadjusted $100-\mathrm{m}$ point-counts provide appropriate indices of relative abundance of grassland songbirds and that assumptions of distance sampling cannot be met in this ecosystem (Henderson and Davis 2014), and are also consistent with recommendations in the literature (Johnson 2008). Although recent burns may temporarily increase perceptibility in burned sites, our surveys all occurred at least 10 months following the fires, and by that point vegetation had regrown such that visibility of birds was similar among treatments. Because the objectives of this study were to compare habitat associations of grassland birds among different management regimes within grasslands, absolute density estimates were not necessary (and are not possible; Efford and Dawson 2009). Bearing all these factors in mind, we concluded that unadjusted point-counts would provide us with the most appropriate index of relative abundance of our focal species, among available options (see also Johnson 2008, Grant et al. 2010, Roberts et al. 2012, Davis et al. 2013).

\section{Vegetation surveys}

Vegetation structure (vegetation biomass and height, and litter depth) was assessed within each point-count plot from mid-June to mid-July, 2008 through 2010; funding limitations prevented us from collecting structural data in 2011. Structure was measured at 50 and $100 \mathrm{~m}$ from the center of each point-count plot in each cardinal direction. Vegetation biomass was estimated using a visual obstruction reading on a Robel pole. Height was recorded when $>50 \%$ of the pole was visually obstructed by vegetation, determined from a distance of $4 \mathrm{~m}$ and at a height of $1 \mathrm{~m}$ (Robel et al. 1970). Height and litter depth were measured with a meter stick.

In 2007, because of funding limitations, vegetation structure points were distributed differently within plots. In burned plots, we only measured vegetation structure at three plots per cluster, and in four frames per plot, each along a cardinal direction and at a random distance from the center of the plot. Vegetation structure for the unburned plots was collected from a separate study taking place in our unburned plots, which used 10 vegetation structure points per plot, all placed within a $20 \mathrm{~m}$ x 50 $\mathrm{m}$ rectangular Whittaker plot in the southern portion of each point-count plot (Koper et al. 2008). Because our results suggest no evidence that temporal or treatment patterns in vegetation structure were driven by data from 2007 (e.g. Fig. 3), it seems unlikely that this discrepancy in the pattern of frames within plots affected our conclusions. 
Fig. 3. Habitat structure per plot (3.2 ha) for (a) vegetation height, (b) vegetation biomass, and (c) litter depth in burnedgrazed (long dashed line), burned-ungrazed (double line), unburned-grazed (solid line), and unburned-ungrazed (short dashed line) sites in Grasslands National Park of Canada and Mankota Community Pastures, southern Saskatchewan, 2007 to 2010. Burned trends are shown in black, unburned trends in red. Only the mean value for the data from each treatment per year is shown, to simplify the graphs and facilitate interpretation.

(a)

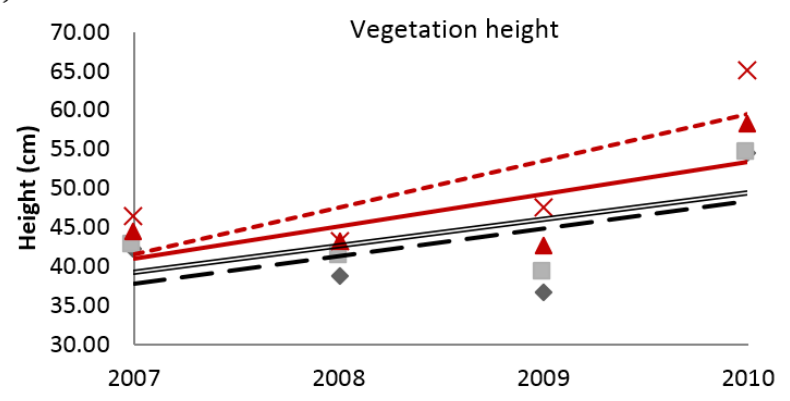

(b)

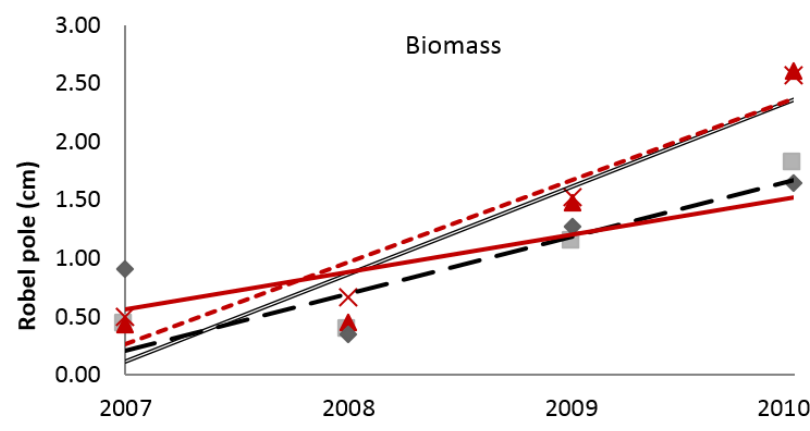

(c)

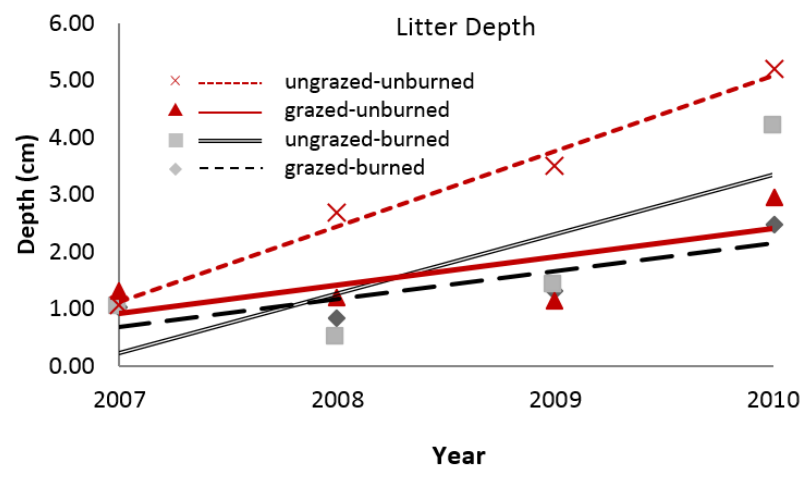

\section{Data analysis}

Songbird community diversity and composition

Species richness was calculated using the total number of songbirds of any species per point-count plot. The ShannonWiener heterogeneity index was used to calculate heterogeneity because it is sensitive to occurrence of rare species, which are of special interest because they may include species at risk (Kempton
1979). For the analyses, the Shannon-Wiener heterogeneity index, $H^{\prime}$, was scaled to units of species by using the exponential form, $e^{H^{\prime}}$, to facilitate interpretation.

Sørensen's quantitative index was used to test for community similarity, based on species diversity and relative abundances, among treatments across years (Jongman et al. 1995, Husté and Boulinier 2011). Because the index is sensitive to sample size, 15 plots were randomly selected within each treatment type per year because there were only 15 unburned-grazed plots in 2010, because of the loss of pasture 10. Linear regression (PROC GENMOD; SAS 9.2, 2009) was used to evaluate whether community similarity increased as time since burning increased among all treatment pair combinations. Diagnostic graphs were used to confirm that distributions of residuals were approximately normal and symmetrical (Draper and Smith 1981).

\section{Vegetation structure, songbird relative abundance, and diversity}

Generalized linear mixed models (GLMMs) were used to analyze effects of burning, grazing, and time since burning occurred (year) on songbird relative abundance, community richness, and heterogeneity, and on habitat structure (PROC GLIMMIX; SAS 9.2, 2009), using a frequentist approach (Mundry 2011). Mixed models allowed us to control for autocorrelation among years within plots, and plots within clusters, by incorporating random variables (plot and/or cluster). For avian species analyses, a negative binomial error structure and log link function was used, based on diagnostic graphs and deviance/df ratios. Diagnostic graphs demonstrated that residuals of avian richness and heterogeneity, and all habitat variables, were distributed approximately normally and thus a Gaussian distribution and identity link function were used for those variables. Degrees of freedom (df) were calculated using the between-within method.

The interaction term burning $\times$ grazing was included to determine whether effects of burning varied with presence or absence of livestock grazing immediately following burns, and the interaction term year $\times$ burning $\times$ grazing was used to evaluate whether effects of burning and grazing declined as time since burning increased. Significant differences between the slopes of ungrazed-unburned sites compared to slopes of the other treatments demonstrated significant differences between these treatments in trends over time. We used (a) the significant differences in slopes, and (b) the comparison between the points in time (i.e., along the $\mathrm{X}$ axis) at which predicted trends for unburned-grazed and burned-grazed, and unburned-ungrazed and burned-ungrazed treatments intersected (i.e., the point in time at which abundance of each species was predicted to be the same in burned and unburned pastures of the same grazing treatment), to test the prediction that effects of burning would last longer in grazed than ungrazed sites. We were unable to compare these intersection points statistically, because in all cases at least one of the intersections was predicted to occur outside the range of our data (i.e., at more than five years post-burn), precluding calculation of confidence intervals for those points. Therefore, we compared those points in time qualitatively, and thus with caution.

Effects of grazing and burning were assessed for relative abundance of ten focal species that occurred in at least $10 \%$ of point-count plots: Baird's Sparrow, Brown-headed Cowbird, Chestnut-collared Longspur, Clay-colored Sparrow, Horned 
Table 1. Interactions among year, burning, and grazing on songbird species abundances in Grasslands National Park of Canada from 2007 to 2011; slopes were compared against the slope for year*unburned*ungrazed when analyzing the interaction between year and treatment. For conciseness, only species that showed at least one significant result are listed.

\begin{tabular}{|c|c|c|c|c|c|}
\hline Species/Index & Fixed Variable & $\beta$ & $S E$ & $d f$ & $p$-value \\
\hline \multirow[t]{7}{*}{ Songbird richness } & Year & 1.171 & 0.143 & 263 & $<0.001$ \\
\hline & Burned & 0.204 & 0.683 & 11 & 0.771 \\
\hline & Grazed & 0.400 & 0.657 & 11 & 0.555 \\
\hline & Burned*Grazed & -0.165 & 0.933 & 11 & 0.863 \\
\hline & Year*Burned*Grazed & -0.293 & 0.199 & 263 & 0.143 \\
\hline & Year*Burned*Ungrazed & 0.123 & 0.205 & 263 & 0.549 \\
\hline & Year*Unburned*Grazed & -0.245 & 0.201 & 263 & 0.224 \\
\hline Shannon-Wiener & Year & 0.827 & 0.115 & 263 & $<.001$ \\
\hline Index of & Burned & 0.545 & 0.557 & 11 & 0.350 \\
\hline Songbird & Grazed & 0.535 & 0.537 & 11 & 0.340 \\
\hline \multirow[t]{4}{*}{ Heterogeneity } & Burned*Grazed & -0.730 & 0.761 & 11 & 0.358 \\
\hline & Year*Burned*Grazed & -0.190 & 0.160 & 263 & 0.238 \\
\hline & Year*Burned*Ungrazed & 0.0283 & 0.165 & 263 & 0.864 \\
\hline & Year*Unburned*Grazed & -0.252 & 0.161 & 263 & 0.119 \\
\hline Baird's Sparrow & Year & -0.088 & 0.041 & 359 & 0.034 \\
\hline \multirow[t]{6}{*}{ (Ammodramus bairdii) } & Burned & -1.114 & 0.355 & 11 & 0.009 \\
\hline & Grazed & -0.372 & 0.317 & 11 & 0.266 \\
\hline & Burned*Grazed & 0.139 & 0.502 & 11 & 0.787 \\
\hline & Year*Burned*Grazed & 0.214 & 0.077 & 359 & 0.006 \\
\hline & Year*Burned*Ungrazed & 0.231 & 0.074 & 359 & 0.002 \\
\hline & Year*Unburned*Grazed & 0.039 & 0.063 & 359 & 0.534 \\
\hline Chestnut-collared & Year & 0.139 & 0.073 & 359 & 0.058 \\
\hline Longspur & Burned & 1.580 & 0.438 & 11 & 0.004 \\
\hline \multirow{5}{*}{ (Calcarius ornatus) } & Grazed & 1.312 & 0.427 & 11 & 0.011 \\
\hline & Burned*Grazed & -1.1147 & 0.550 & 11 & 0.068 \\
\hline & Year*Burned*Grazed & -0.200 & 0.086 & 359 & 0.021 \\
\hline & Year*Burned*Ungrazed & -0.277 & 0.092 & 359 & 0.003 \\
\hline & Year*Unburned*Grazed & 0.094 & 0.086 & 359 & 0.276 \\
\hline Clay-colored & Year & -0.147 & 0.127 & 359 & 0.249 \\
\hline Sparrow & Burned & -1.203 & 1.342 & 11 & 0.389 \\
\hline \multirow[t]{5}{*}{ (Spizella pallida) } & Grazed & -4.711 & 2.076 & 11 & 0.044 \\
\hline & Burned*Grazed & 4.866 & 2.485 & 11 & 0.076 \\
\hline & Year*Burned*Grazed & 0.272 & 0.219 & 359 & 0.215 \\
\hline & Year*Burned*Ungrazed & 0.336 & 0.246 & 359 & 0.172 \\
\hline & Year*Unburned*Grazed & 0.773 & 0.409 & 359 & 0.060 \\
\hline Horned Lark & Year & -0.105 & 0.119 & 359 & 0.379 \\
\hline \multirow[t]{6}{*}{ (Eremophila alpestris) } & Burned & 1.349 & 0.585 & 11 & 0.042 \\
\hline & Grazed & 1.166 & 0.562 & 11 & 0.062 \\
\hline & Burned*Grazed & -1.355 & 0.732 & 11 & 0.091 \\
\hline & Year*Burned*Grazed & -0.049 & 0.143 & 359 & 0.734 \\
\hline & Year*Burned*Ungrazed & -0.284 & 0.165 & 359 & 0.086 \\
\hline & Year*Unburned*Grazed & -0.191 & 0.149 & 359 & 0.202 \\
\hline Sprague's Pipit & Year & 0.007 & 0.047 & 359 & 0.876 \\
\hline \multirow[t]{6}{*}{ (Anthus spragueii) } & Burned & -0.999 & 0.305 & 11 & 0.007 \\
\hline & Grazed & -0.150 & 0.236 & 11 & 0.538 \\
\hline & Burned*Grazed & -0.078 & 0.431 & 11 & 0.860 \\
\hline & Year*Burned*Grazed & 0.230 & 0.084 & 359 & 0.006 \\
\hline & Year*Burned*Ungrazed & 0.200 & 0.084 & 359 & 0.017 \\
\hline & Year*Unburned*Grazed & 0.056 & 0.065 & 359 & 0.392 \\
\hline Western & Year & -0.147 & 0.158 & 359 & 0.353 \\
\hline Meadowlark & Burned & -0.345 & 0.769 & 11 & 0.663 \\
\hline \multirow[t]{5}{*}{ (Sturnella neglecta) } & Grazed & -0.365 & 0.758 & 11 & 0.640 \\
\hline & Burned*Grazed & 0.082 & 1.070 & 11 & 0.940 \\
\hline & Year*Burned*Grazed & 0.366 & 0.212 & 359 & 0.084 \\
\hline & Year*Burned*Ungrazed & 0.313 & 0.213 & 359 & 0.143 \\
\hline & Year*Unburned*Grazed & 0.186 & 0.213 & 359 & 0.383 \\
\hline
\end{tabular}

Lark, McCown's Longspur, Sprague’s Pipit, Savannah Sparrow, Vesper Sparrow, and Western Meadowlark. All but Brownheaded Cowbirds are grassland obligates (Vickery et al. 1999).

\section{RESULTS}

Songbird species richness and heterogeneity increased over the years of the study, but were not significantly associated with burning or grazing or their interaction (Table 1). Only communities in unburned-ungrazed and burned-ungrazed sites showed an increase in similarity over time $\left(R^{2}=0.757, \beta=8.969\right.$, $\mathrm{SE}=2.931, \mathrm{df}=4, p=0.055)$, from $51.49 \%$ in 2007 to $82.20 \%$ in 2011 (particularly in the final two years), while there was no significant trend in increasing similarity over time among other treatment comparisons ( $p>0.338$; Table 2). 
Table 2. Sørensen's quantitative indices comparing the songbird community in burned-grazed (BG), burned-ungrazed (BUG), unburned-grazed (UBG), and unburned-ungrazed (UBUG) sites in southern Saskatchewan, 2007 through 2011.

\begin{tabular}{cccc}
\hline \hline Year & BG-BUG & BG-UBG & BG-UBUG \\
\hline 2007 & 84.11 & 68.20 & 48.08 \\
2008 & 82.28 & 75.84 & 61.42 \\
2009 & 82.24 & 79.46 & 50.00 \\
2010 & 69.62 & 79.87 & 66.24 \\
2011 & 80.37 & 51.81 & 63.06 \\
& & & \\
2007 & UBUG-BUG & UBUG-UBG & BUG-UBG \\
2008 & 51.49 & 76.10 & 72.99 \\
2009 & 58.96 & 68.84 & 83.00 \\
2010 & 56.19 & 60.91 & 84.40 \\
2011 & 87.23 & 82.39 & 79.88 \\
\hline
\end{tabular}

Consistent with our predictions, initially, Baird's Sparrows and Sprague's Pipits had their highest abundances in the undisturbed treatment, and lowest abundances in sites with both burning and grazing, while Chestnut-collared Longspurs and Horned Larks showed the reverse pattern (Fig. 4, Table 1). However, in contrast to our predictions, Clay-colored Sparrows and Western Meadowlarks relative abundances did not decline in burned sites (Fig. 4, Table 1), suggesting that abundance of shrubs such as silver sagebrush remained sufficient for these species despite burns. Consistent with our predictions, habitat generalists (Brown-headed Cowbird, Savannah Sparrow, and Vesper Sparrow) did not respond significantly to burning, grazing, or their interaction $(P>0.1)$. Parameter estimates and statistical significance demonstrate that initially, Sprague's Pipits and Baird's Sparrows both showed a stronger avoidance of burned sites than grazed sites, but effects of burning were similarly negative in grazed compared with ungrazed sites (Fig. 4, Table 1). Conversely, Chestnut-collared Longspurs and Horned Larks initially responded similarly and positively to burning and grazing, but burning resulted in smaller positive effects in grazed compared with ungrazed sites (Fig. 4, Table 1). The models for McCown's Longspur did not converge, probably because of low sample sizes.

For all four species that showed consistent and strong responses to burning or grazing (Baird's Sparrows, Sprague's Pipits, Chestnut-collared Longspurs, and Horned Larks), trends over time in their relative abundances within treatments ( $\beta$, or slope) did not differ between unburned-grazed and unburned-ungrazed sites, suggesting that effects of grazing did not change over time, consistent with our predictions (Table 1). However, trends over time in burned sites differed from trends over time in unburned sites, such that by the fourth and fifth year postburn, most differences between burned and unburned treatments had declined (Fig. 4, Table 1). Predicted slopes for ungrazed sites converged, or would be predicted to converge, earlier than for grazed sites for Sprague's Pipits, Horned Larks, and Claycoloured Sparrows, consistent with the feedback hypothesis, but that pattern did not occur for Baird's Sparrows, Western Meadowlarks, or Chestnut-collared Longspurs (Fig. 4). Our qualitative comparison might overestimate differences between intersection points for grazed and ungrazed sites because they could not be compared statistically; thus, we can conclude that three or fewer of the six species that responded significantly to burning and/or grazing showed evidence for a positive feedback mechanism between burning and grazing, whereas three or more of the six species did not.

Fig. 4. Mean abundance per plot (3.2 ha) for (a) Baird's Sparrow (Ammodramus bairdii), (b) Chestnut-collared Longspur (Calcarius ornatus), (c) Sprague's Pipit (Anthus spragueii), (d) Horned Lark (Eremophila alpestris), (e) Claycolored Sparrow (Spizella pallida), and (f) Western Meadowlark (Sturnella neglecta) in burned-grazed (long dashed line), burned-ungrazed (double line), unburned-grazed (solid line) and unburned-ungrazed (short dashed line) sites in Grasslands National Park of Canada and Mankota Community Pastures, southern Saskatchewan, 2007 to 2011. Burned trends are shown in black, unburned trends in red. Only the mean value for the data from each treatment per year is shown, to simplify the graphs and facilitate interpretation.
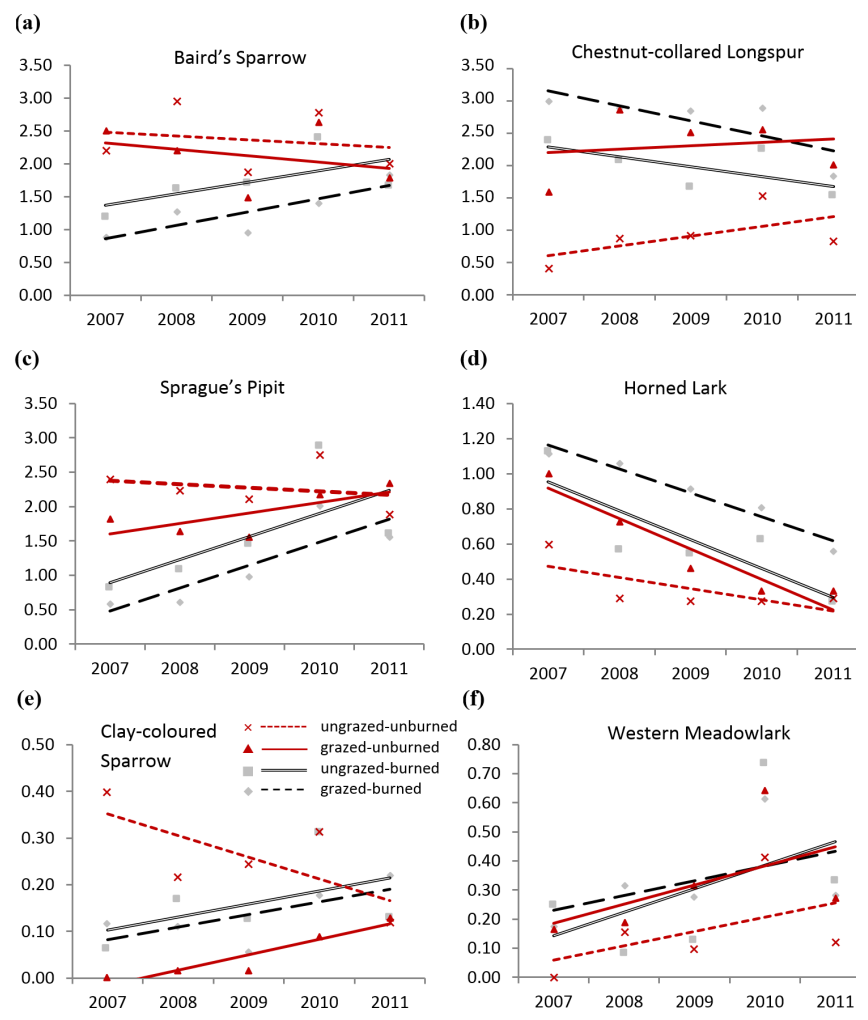

Vegetation height, biomass, and litter depth all increased over the duration of the study, presumably in response to relatively high precipitation during our study (Government of Canada 2011; Fig. 3 , Table 3). Vegetation was tallest in unburned-ungrazed sites, and this difference in vegetation height among treatments increased over time (Fig. 3, Table 3). Similarly, differences in biomass and litter depth between grazed and ungrazed sites increased over time (Fig. 3, Table 3). Surprisingly, we detected few significant effects of burning on our measures of vegetation structure (Table 3). 
Table 3. Interactions among year, burning, and grazing on habitat structure in Grasslands National Park of Canada from 2007 to 2010; slopes were compared against the slope for year* unburned*ungrazed when analyzing the interaction between year and treatment.

\begin{tabular}{|c|c|c|c|c|c|}
\hline Habitat characteristic & Fixed Variable & $\beta$ & $S E$ & $d f$ & $p$-value \\
\hline \multirow[t]{7}{*}{ Vegetation height } & Year & 0.161 & 0.029 & 240 & $<0.001$ \\
\hline & Burned & 0.146 & 0.101 & 11 & 0.176 \\
\hline & Grazed & 0.159 & 0.102 & 11 & 0.145 \\
\hline & Burned*Grazed & -0.212 & 0.134 & 11 & 0.142 \\
\hline & Year*Burned*Grazed & -0.081 & 0.028 & 240 & 0.004 \\
\hline & Year*Burned*Ungrazed & -0.086 & 0.029 & 240 & 0.003 \\
\hline & Year*Unburned*Grazed & -0.080 & 0.029 & 240 & 0.007 \\
\hline \multirow[t]{7}{*}{ Biomass } & Year & 0.809 & 0.062 & 237 & $<0.001$ \\
\hline & Burned & 0.183 & 0.288 & 11 & 0.539 \\
\hline & Grazed & 0.919 & 0.299 & 11 & 0.009 \\
\hline & Burned*Grazed & -0.536 & 0.383 & 11 & 0.190 \\
\hline & Year*Burned*Grazed & -0.333 & 0.079 & 237 & $<0.001$ \\
\hline & Year*Burned*Ungrazed & -0.062 & 0.080 & 237 & 0.440 \\
\hline & Year*Unburned*Grazed & -0.452 & 0.082 & 237 & $<0.001$ \\
\hline \multirow[t]{7}{*}{ Litter depth } & Year & 1.296 & 0.159 & 240 & $<0.001$ \\
\hline & Burned & -0.667 & 0.649 & 11 & 0.326 \\
\hline & Grazed & 0.479 & 0.660 & 11 & 0.483 \\
\hline & Burned*Grazed & 0.513 & 0.855 & 11 & 0.561 \\
\hline & Year*Burned*Grazed & -0.812 & 0.200 & 11 & $<0.001$ \\
\hline & Year*Burned*Ungrazed & -0.270 & 0.205 & 11 & 0.189 \\
\hline & Year*Unburned*Grazed & -0.804 & 0.210 & 11 & $<0.001$ \\
\hline
\end{tabular}

\section{DISCUSSION}

Our results provide conflicting evidence for and against the hypothesis that a positive feedback mechanism between burning and grazing results in a longer recovery period in grazed than ungrazed sites (Bailey 1988, Fuhlendorf et al. 2006). The significant increase over time in songbird community similarity between burned-ungrazed and unburned-ungrazed pastures, but not between burned-grazed and unburned-grazed sites, suggests that grazing extended the length of time that burning influenced the songbird community. Similarly, relative abundances of some of the avian species that responded to disturbance showed more rapid convergence of relative abundances in ungrazed than grazed sites. These results are consistent with the hypothesis that the feedback loop caused by increased palatability of vegetation regrowth following fires (Bailey 1988) may slow the recovery of the grassland ecosystem (Fuhlendorf et al. 2006). However, we did not detect these patterns for many other avian species we studied, or for vegetation structure. Cumulatively, our results provide relatively little support for the positive feedback hypothesis, though we note that the presence of low abundances of native ungulates in the region might have somewhat weakened our ability to detect these effects.

The lack of effects of burning on vegetation structure was surprising, given that the burns were visible and obvious (e.g., Fig. 1); that the avian species we studied responded significantly and predictably to burning, suggesting ecologically relevant changes in habitat structure; and that previous studies have found significant effects of fire on vegetation structure in mixedgrass prairies (e.g., Grant et al. 2010). This suggests that there were effects of burning on structural or compositional measures of vegetation that we did not measure, that effects of burning occurred at a scale we did not measure, or that our sample sizes were too low to detect effects of burning on vegetation structure.
Burning may have long-term effects on vegetation by altering the nutrient content of the soil, making the soil more impermeable to water, or increasing evaporation rates through the removal of litter (Shay et al. 2001, Erichsen-Arychuk et al. 2002). Alternatively, burning may favor the growth of shorter grass species that prefer disturbance, such as blue grama grass (Smoliak et al. 1972), producing long-term changes in the vegetation community. Avian habitat selection may also be driven by more than vegetation structure. Many grassland songbird species also respond to edge effects, patch size and shape (Davis et al. 2006, Koper and Schmiegelow 2006), and sometimes soil conditions (Wiens et al. 2008). The range of vegetation structure available five years after burns apparently included conditions suitable for many grassland songbirds in this northern mixed-grass prairie (see also Johnson 1997).

For Chestnut-collared Longspurs and Horned Larks, effects of grazing or burning alone were similar, suggesting that in some cases a single source of disturbance had a similar effect on the avian community, regardless of whether that was burning or grazing. However, ecological effects of burning and grazing were not identical. Burning initially had a greater effect than grazing on species that tend to react negatively to disturbance, including Sprague's Pipits and Baird's Sparrows. Further, effects of burning differed in grazed and ungrazed sites for Chestnut-collared Longspurs, Horned Larks, and Clay-coloured Sparrows, demonstrating an interaction between burning and grazing. Burning can result in a change in the vegetation community (an increase in grasses and decrease in forbs) and usually a reduction in accumulated litter (Madden et al. 1999). However, litter begins to reaccumulate almost immediately following a burn and accumulates at a rate that is mostly governed by vegetation growth and grazing intensity, because grazing suppresses litter accumulation through the removal of dead standing vegetation 
(Madden et al. 1999, Shay et al. 2001, Collins and Smith 2006). Although initial effects of burning can be greater than effects of grazing, over the long term, grazing may have more permanent effects if burns occur at natural or long intervals (Wright and Bailey 1982). Conversely, differences in effects of burned and grazed sites might simply arise because of species-specific habitat preferences (Johnson 1997, Derner et al. 2009, Roberts et al. 2012). Differences in ecological effects of burning and grazing are important from a conservation perspective, because burning is actively suppressed in mixed-grass prairies. However, our results demonstrate that livestock grazing alone cannot replicate historic conditions created by the interplay of fire and ungulate grazing.

Although we detected a number of effects of burning and grazing on the songbird community and on individual species, in contrast to our predictions, this did not result in higher species diversity in disturbed sites. This is surprising because several previous studies in the fescue and mixed-grass prairies have found an increase in avian species richness after a disturbance (Pylypec 1991, Madden et al. 1999, 2000, Danley et al. 2004; but see Grant et al. 2010). This pattern has sometimes been explained by the preference by most endemic grassland species for short, sparse vegetation with little litter, which was presumably shaped by the evolutionary history of the North American prairies, during which intense disturbances occurred frequently (Knopf 1994, Brawn et al. 2001, Fuhlendorf et al. 2006). However, our focal species have preferences for a wide range of habitat conditions, from short and sparse (e.g. Chestnut-collared Longspur; Derner et al. 2009) to tall and dense vegetation (e.g. Baird's Sparrow; Green et al. 2002), and songbird community composition differed between disturbed and undisturbed sites. Our results suggest that species with preferences for undisturbed sites are replaced by species with preferences for disturbed sites following fires in mixed-grass prairies, and thus diversity does not change, despite a change in community composition. Not surprisingly, habitat generalists showed little sensitivity to burning or grazing.

Grasslands National Park is part of a semiarid ecosystem, and is prone to prolonged periods of drought. Consequently, management practices and grazing regimes need to be conservative (Bailey et al. 2010). This study occurred as the mixedgrass prairies transitioned from a dry to wet cycle (Government of Canada 2011). As such, caution must be used in applying the results of our research to conservation planning. Succession is likely to take longer during drier periods (Madden et al. 1999), and may also be altered by ecological impacts of climate change in this region (Thorpe 2011). The apparent population growth of Western Meadowlarks may be temporary and may not continue once precipitation returns to historical averages. Further, ecological effects of fire vary with burn intensity and fuel load (e. g., Bradstock and Auld 1995, Grant et al. 2010; but see Roberts et al. 2012), and thus more or less intense burns might have different ecological results. We also could not address potential regional differences in responses to disturbance with our data set, and also caution that imperfect detectability of birds during abundance surveys could affect results, for example, by increasing variance and thus reducing statistical power.

Effects of burning and grazing differ from one another, and should be regarded as separate and distinct disturbances with potential for resulting in interacting effects on grassland songbird communities. Although cattle grazing can contribute toward conserving a diverse avian community, it does not replace the ecological roles of fire. Burning should be used as a management tool on ungrazed mixed-grass prairie where the goal of grassland management is avian conservation, such as in protected areas. Because individual species respond differently and sometimes in contrasting ways to disturbances, there is a need to maintain prairie habitats at a variety of successional stages. Incorporating burning into grassland management can contribute toward providing a mosaic of suitable habitats for various songbird species.

Responses to this article can be read online at: http://www.ace-eco.org/issues/responses.php/692

\section{Acknowledgments:}

We thank the Mankota community pastures and Parks Canada, whose land was used for songbird and habitat surveys. Research was funded by Parks Canada and NSERC (2007 through 2011), with additional financial support from the Province of Manitoba through the Manitoba Graduate Scholarship (2008, 2009), the Province of Saskatchewan through the Fish and Wildlife Development Fund Student Award (2008), and the Sixth Prairie Conservation and Endangered Species Conference Fellowship (2008) administered by the University of Manitoba. Two anonymous reviewers, the subject editor, and Dr. Norris provided helpful recommendations on improving the manuscript.

\section{LITERATURE CITED}

Abouguendia, Z. M. 1990. A practical guide to planning for management and improvement of Saskatchewan rangeland: range plan development. Saskatchewan Agriculture Development Fund, Regina, Saskatchewan, Canada.

Askins, R. A., F. C. Ramirez, B. C. Dale, C. A. Haas, J. R. Herkert, F. L. Knopf, P. D. Vickery. 2007. Conservation of grassland birds in North America: understanding ecological processes in different regions. Ornithological Monographs 64:1-46.

Bailey, A. W. 1988. Understanding fire ecology for range management. Pages 527-557 in P. T. Tueller, editor. Vegetation science applications for rangeland analysis and management. Kluwer Academic, Boston, Massachusetts, USA. http://dx.doi. org/10.1007/978-94-009-3085-8_21

Bailey, A., D. McCartney, and M. Schellenberg. 2010. Management of Canadian prairie rangeland. Government of Canada, Agriculture and Agri-Food Canada, Ottawa, Ontario, Canada.

Bradstock, R. A., and T. D. Auld. 1995. Soil temperatures during experimental bushfires in relation to fire intensity: consequences for legume germination and fire management in south-eastern Australia. Journal of Applied Ecology 32:76-84. http://dx.doi. org/10.2307/2404417

Brawn, J. D., S. K. Robinson, and F. R. Thompson III. 2001. The role of disturbance in the ecology and conservation of birds. 
Annual Review of Ecology and Systematics 32:251-276. http://dx. doi.org/10.1146/annurev.ecolsys.32.081501.114031

Brudvig, L. A., C. M. Mabry, J. R. Miller, and T. A. Walker. 2007. Evaluation of central North American prairie management based on species diversity, life form, and individual species metrics. Conservation Biology 21:864-874. http://dx.doi.org/10.1111/ j.1523-1739.2006.00619.x

Collins, S. L., and M. D. Smith. 2006. Scale-dependent interaction of fire and grazing on community heterogeneity in tallgrass prairie. Ecology 87:2058-2067. http://dx.doi.org/10.1890/0012-9658 (2006)87[2058:SIOFAG]2.0.CO;2

Danley, R. F., R. K. Murphy, and E. M. Madden. 2004. Species diversity and habitat of grassland passerines during grazing of a prescribe-burned, mixed-grass prairie. Western North American Naturalist 64:72-77.

Davis, S. K., R. M. Brigham, T. L. Shaffer, and P. C. James. 2006. Mixed-grass prairie passerines exhibit weak and variable responses to patch size. Auk 123:807-821. http://dx.doi. org/10.1642/0004-8038(2006)123[807:MPPEWA]2.0.CO;2

Davis, S. K., R. J. Fisher, S. L. Skinner, T. L. Shaffer, and R. M. Brigham. 2013. Songbird abundance in native and planted grassland varies with type and amount of grassland in the surrounding landscape. Journal of Wildlife Management 77:908-919. http://dx.doi.org/10.1002/jwmg.537

Derner, J. D., W. K. Lauenroth, P. Stapp, and D. J. Augustine. 2009. Livestock as ecosystem engineers for grassland bird habitat in the western Great Plains of North America. Rangeland Ecology and Management 62:111-118. http://dx.doi.org/10.2111/08-008.1

Draper, N. R., and H. Smith. 1981. Applied regression analysis Second edition. Wiley, New York, New York, USA.

Efford, M. G., and D. K. Dawson. 2009. Effect of distance-related heterogeneity on population size estimates from point counts. Auk 126:100-111. http://dx.doi.org/10.1525/auk.2009.07197

Erichsen-Arychuk, C., E. W. Bork, and A. W. Bailey. 2002. Northern dry mixed prairie responses to summer wildlife and drought. Journal of Range Management 55:164-170. http://dx.doi. org/10.2307/4003352

Farnsworth, G. L., K. H. Pollock, J. D. Nichols, T. R. Simons, J. E. Hines, and J. R. Sauer. 2002. A removal model for estimating detection probabilities from point-count surveys. Auk 119:414-425. http://dx.doi.org/10.1642/0004-8038(2002)119[0414: ARMFED]2.0.CO;2

Fritcher, S. C., M. A. Rumble, and L. D. Flake. 2004. Grassland bird densities in seral stages of mixed-grass prairie. Journal of Range Management 57:351-357. http://dx.doi.org/10.2307/4003858

Fuhlendorf, S. D., W. C. Harrell, D. M. Engle, R. G. Hamilton, C. A. Davis, and D. M. Leslie, Jr. 2006. Should heterogeneity be the basis for conservation? Grassland bird response to fire and grazing. Ecological Applications 16:1706-1716. http://dx.doi. org/10.1890/1051-0761(2006)016[1706:SHBTBF]2.0.CO;2

Government of Canada. 2011. National climate data and information archive. Government of Canada, Ottawa, Ontario, Canada. [online] URL: http://www.climate.weatheroffice.gc.ca
Government of Canada. 2012. Species at risk public registry. Government of Canada, Ottawa, Ontario, Canada. [online] URL: http://www.registrelep-sararegistry.gc.ca

Grant, T. A., E. M. Madden, T. L. Shaffer, and J. S. Dockens. 2010. Effects of prescribed fire on vegetation and passerine birds in northern mixed-grass prairie. Journal of Wildlife Management 74:1841-1851. http://dx.doi.org/10.2193/2010-006

Green, M. T., P. E. Lowther, S. L. Jones, S. K. Davis, and B. C. Dale. 2002. Baird's Sparrow. In A. Poole and F. Gill, editors. The birds of North America. The Birds of North America, Philadelphia, Pennsylvania, USA.

Henderson, A. E., and S. K. Davis. 2014. Rangeland health assessment: a useful tool for linking range management and grassland bird conservation? Rangeland Ecology and Management 67:88-98. http://dx.doi.org/10.2111/REM-D-12-00140.1

Higgins, K. F. 1986. Interpretation and compendium of historical fire accounts in the northern Great Plains. Resource Publication No. 161. Department of the Interior, U.S. Fish and Wildlife Service, Washington, D.C., USA.

Hines, J. E. 2000. DOBSERV - A double-observer approach for estimating detection probability and abundance from avian point counts as described in Nichols et. al. (2000). U.S. Geological Survey, Patuxent Wildlife Research Center, Laurel, Maryland, USA. [online] URL: http://www.mbr-pwrc.usgs.gov/software/ dobserv.shtml

Husté, A., and T. Boulinier. 2011. Determinants of bird community composition on patches in the suburbs of Paris, France. Biological Conservation 144:243-252. http://dx.doi. org/10.1016/j.biocon.2010.08.022

Johnson, D. H. 1997. Effects of fire on bird populations in mixedgrass prairie. Pages 181-206 in F. L. Knopf and F. B. Samson, editors. Ecology and conservation of Great Plains vertebrates. Ecological studies, volume 125. Springer, New York, New York, USA. http://dx.doi.org/10.1007/978-1-4757-2703-6_8

Johnson, D. H. 2008. In defense of indices: the case of bird surveys. Journal of Wildlife Management 72:857-868. http://dx. doi.org/10.2193/2007-294

Jongman, R. H. G., C. J. F. Ter Braak, and O. F. R. van Tongeren. 1995. Data analysis in community and landscape ecology. Cambridge University Press, Cambridge, UK. http://dx.doi. org/10.1017/CBO9780511525575

Kempton, R. A. 1979. The structure of species abundance and measurement of diversity. Biometrics 35:307-321. http://dx.doi. org/10.2307/2529952

Knopf, F. L. 1994. Avian assemblages on altered grasslands. Studies in Avian Biology 15:247-257.

Knopf, F. L. 1996. Prairie legacies - birds. Pages 135-148 in F. Samson and F. Knopf, editors. Prairie conservation: preserving North America's most endangered ecosystem. Island Press, Washington, D.C., USA.

Knopf, F. L., and F. B. Samson. 1997. Conservation of grassland vertebrate. Pages 273-289 in F. L. Knopf and F. B. Samson, editors. Ecology and conservation of Great Plains vertebrates. 
Ecological studies, volume 125. Springer, New York, New York, USA. http://dx.doi.org/10.1007/978-1-4757-2703-6_11

Koper, N., and F. K. K. Schmiegelow. 2006. A multi-scaled analysis of avian response to habitat amount and fragmentation in the Canadian dry mixed-grass prairie. Landscape Ecology 21:1045-1059. http://dx.doi.org/10.1007/s10980-006-0004-0

Koper, N., D. C. Henderson, J. F. Wilmshurst, P. J. Fargey, and R. A. Sissons. 2008. Design and analysis of rangeland experiments along continuous gradients. Rangeland Ecology and Management 61:605-613. http://dx.doi.org/10.2111/08-046.1

Kruse, A. D., and B. S. Bowen. 1996. Effects of grazing and burning on densities and habitats of breeding ducks in North Dakota. Journal of Wildlife Management 60:233-246. http://dx. doi.org/10.2307/3802221

Lesica, P., and S. V. Cooper. 1999. Succession and disturbance in sandhills vegetation: constructing models for managing biological diversity. Conservation Biology 13:293-302. http://dx. doi.org/10.1046/j.1523-1739.1999.013002293.x

Lueders, A. S., P. L. Kennedy, and D. H. Johnson. 2006. Influences of management regimes on breeding bird densities and habitat in mixed-grass prairie: an example from North Dakota. Journal of Wildlife Management 70:600-606. http://dx.doi.org/10.2193/0022-541X (2006)70[600:IOMROB]2.0.CO;2

Madden, E. M., A. J. Hansen, and R. K. Murphy. 1999. Influence of prescribed fire history on habitat and abundance of passerine birds in northern mixed-grass prairie. Canadian Field-Naturalist 113:627-640.

Madden, E. M., R. K. Murphy, A. J. Hansen, and L. Murray. 2000. Models for guiding management of prairie bird habitat in northwestern North Dakota. American Midland Naturalist 144:337-392. http://dx.doi.org/10.1674/0003-0031(2000)144[0377: MFGMOP]2.0.CO;2

Mundry, R. 2011. Issues in information theory-based statistical inference - a commentary from a frequentist's perspective. Behavioral Ecology and Sociobiology 65:57-68. http://dx.doi. org/10.1007/s00265-010-1040-y

Parks Canada. 2002. Grasslands National Park of Canada management plan. Parks Canada, Grasslands National Park of Canada, Val Marie, Saskatchewan, Canada.

Powell, A. F. L. A. 2006. Effects of prescribed burns and bison (Bos bison) grazing on breeding bird abundances in tallgrass prairie. Auk 123:183-197. http://dx.doi.org/10.1642/0004-8038 (2006)123[0183:EOPBAB]2.0.CO;2

Pylypec, B. 1991. Impacts of fire on bird populations in a fescue prairie. Canadian Field Naturalist 105:346-349.

Robel, R. J., J. N. Briggs, A. D. Dayton, and L. C. Hulbert. 1970. Relationships between visual obstruction measurements and weight of grassland vegetation. Journal of Range Management 23:295-297. http://dx.doi.org/10.2307/3896225
Roberts, A. J., C. W. Boal, D. B. Wester, S. Rideout-Hanzak, and H. A. Whitlaw. 2012. Grassland bird community responses to large wildfires. Wilson Journal of Ornithology 124:24-30. http:// dx.doi.org/10.1676/10-177.1

Rotella, J. T., E. M. Madden, and A. J. Hansen. 1999. Sampling considerations for estimating density of passerines in grasslands. Studies in Avian Biology 19:237-243.

Royle, J. A., and J. D. Nichols. 2003. Estimating abundance from repeated presence-absence data or point counts. Ecology 84:777-790. http://dx.doi.org/10.1890/0012-9658(2003)084[0777: EAFRPA]2.0.CO;2

Samson, F. B., and F. L. Knopf. 1994. Prairie conservation in North America. BioScience 44:418-421. http://dx.doi. org/10.2307/1312365

Shay, J., D. Kunec, and B. Dyck. 2001. Short-term effects of fire frequency on vegetation composition and biomass in mixed prairie in south-western Manitoba. Plant Ecology 155:157-167. http://dx.doi.org/10.1023/A:1013266700912

Smoliak, S., J. F. Dormaar, and A. Johnston. 1972. Long-term grazing effects on Stipa-Bouteloua prairie soils. Journal of Range Management 25:246-250. http://dx.doi.org/10.2307/3896903

Thorpe, J. 2011. Vulnerability of prairie grasslands to climate change. Saskatchewan Research Council 12855-2E11, Saskatoon, Saskatchewan, Canada.

Vickery, P. D., P. L. Tubaro, J. M. Cardosa da Silva, B. G. Peterjohn, J. R. Herkert, and R. B. Cavalcanti. 1999. Conservation of grassland birds in the Western Hemisphere. Studies in Avian Biology 19:27-46.

Wiens, T. S., B. C. Dale, M. S. Boyce, and G. P. Kershaw. 2008. Three way $k$-fold cross-validation of resource selection functions. Ecological Modelling 212:244-255. http://dx.doi.org/10.1016/j. ecolmodel.2007.10.005

With, K. A., A. W. King, and W. E. Jensen. 2008. Remaining grasslands may not be sufficient to prevent grassland bird declines. Biological Conservation 141:3152-3167. http://dx.doi.org/10.1016/ j.biocon.2008.09.025

Wright, H. A., and A. W. Bailey. 1982. Fire ecology. John Wiley and Sons, New York, New York, USA.

Zimmerman, J. L. 1997. Avian community responses to fire, grazing, and drought in the tallgrass prairie. Pages 167-180 in $\mathrm{F}$. L. Knopf and F. B. Samson, editors. Ecology and conservation of Great Plains vertebrates. Ecological studies, volume 125. Springer, New York, New York, USA. http://dx.doi.org/10.1007/978-1-4757-2703-6_7
Editor-in-Chief: Ryan Norris

Subject Editor: W. Douglas Robinson
Sponsored by the Society of Canadian Ornithologists and Bird Studies Canada Parrainée par la Société des ornithologistes du Canada et Études d'oiseaux Canada

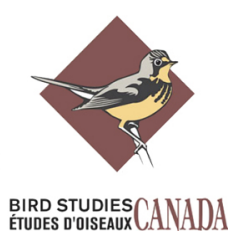

